\title{
Health and poverty: health management by the woman*
}

\section{Saúde e pobreza: o controle da saúde pela mulher}

\author{
Maria de la Luz Alvarez**, Fanny Wurgaft"*
}

\begin{abstract}
ALVAREZ, M. L. \& WURGAFT, F. Health and poverty: health management by the woman. Rev. Saúde públ., S. Paulo, 26: 82-7, 1992. The goal this follow-up study was to relate the mother's marital satisfaction to family health status in a low SES. The random sample was made up of 30 families with children under 7 years old: 15 considered as sick (Group A) and 15 as healthy (Group B). Both group had similar demographic characteristics (age of father and mother, persons per family group and age of children) and SES. Results showed that mothers were those mainly in charge of their family groups. Mothers of Group A were significantly less understanding and more dissatisfied than those of Group B $(p<.05$ and $p<.01)$. Mothers of Group A had significantly more arguments with their partners than those of Group $B(p<.006)$. Heallh care was learned less from the child's own mother in group $A$ than in $B(p<.05)$. Health was considered by mothers of Group A as something that "must be taken care of" more than by those of Group B $(p<.01)$. The behaviours of mothers in choosing one of the health systems was similar in both groups. Dissatisfied mothers were associated more with sick family members during the 6 month follow-up. It is suggested that the satisfaction of the mother is a factor that needs further investigation because health is managed by mothers is the large majority of families.
\end{abstract}

Keywords: Mothers. Personal satisfaction. Family health. Poverty.

\section{Introduction}

Health is a right that should be within the reach of everyone. All individuals strive to maintain or improve their health. This is sought in a varicty of ways, one of them being the State services provided by the State. These provide health care based on policies established by the government. Governments assign priorities according to age groups or to problems that are considered to bc high in the order of priorities for prevention or treatment ${ }^{3}$. This system, called exogenous, has a scientific basis. Use and custom are other ways of treating or preventing diseases. These are mostly acquired from tradition. This system, called endogenous, relies on empirical knowledge and traditional beliefs and practices. The exogenous and endogenous systems coexist to a greatcr or lesser in all countries ${ }^{1,2}, 8,10,16,18,20$. Depending on the accessibility and prestige of each system, either may be used depending on circumstances $6,11,22,23$.

Health systems render the work of the person in

\section{* Grant UNU 1986 \\ ** Instituto de Nutrición y Tecnologia de los Alimentos, Universidad de Chile}

Separatas/Reprints: M. L. Alvarez-Casilla 138-11.Santiago, 11, Chilc charge of family health easier. Usually this person is a woman and, particularly, the mother. This occurs in the grcat majority of cultures where the mother or a grandmother are assumed to be in charge of the maintenance of family health ${ }^{7,13}$.

Studies that have shown that it is the woman who takes care of family heal th, have not taken her emotional state, a variable that may affect her family's health, into consideration. The way in which she manages health situations is conditioned by her background (cmpirical and/or scientific knowledge), her emotional satisfaction, and by the facilitics available to her within her environment.

It is suggested that the greater the mother's marital dissatisfaction the more health problems there will be in her family group, when this latter is of a low socioeconomic status (SES).

\section{Material and Method}

The study was carried out within a single "slum" (Villa Caupolicán)* so that prevailing en-

This is a human group that lives in physically poor conditions and has a low SES - precarious homes located haphazardly in urban areas, without piped water or a scwage system. 
vironmental conditions would be comparable for all the families. First, a census was made to determine the universe of families with at least one child under 6 years of age. The universe consisted of 326 homes which altogether included 1,703 individuals. The census allowed the classification of families into "sick" or "healthy". They were asked if one or more of their members had shown symptoms of sickness ${ }^{23}$ requiring help from one of the health systems (endogenous $=$ healer, or exogenous $=$ western medicine) within the three months prior to the interview. The family which had had symptoms of sickness during this period was considered sick. And the family which had not shown any symptoms over the same period was considered "healthy". After the census was taken, it was found that 72 families met the requirements of this project; $62.5 \%$ belonged to Group A (sick family) and $37.5 \%$ to Group B (healthy family). From each of these groups, 15 families were chosen at random. Finally, the sample was constituted of 30 families 15 of which were "sick" (Group A) and 15 "healthy" (Group B).

The techniques used to gather information for this study were: a) a survey to determine the SES, b) a structured interview to measure personal interrelationships between the couple (with respect to satisfaction, understanding, and having arguments), demographic variables (age, rural or urban origin) and knowledge about health. Qucstions asked of mothers were "closed" and "open" with alternatives, or completely open, c) semistructured interviews were given to find out, on a weckly basis, the health events that occurred within the family related to disease symptoms and the attempts made to recover. In this case, only open questions were asked.

Procedure: Once the first interview ended, the follow-up was made by a social worker and began by visiting all families every week during a 6 . month period so as to keep a record of hcalth problems (health symptoms and treatments) and to see how the mother solved them. The follow-up began in the middle of Fall and ended at the beginning of Spring (the coldest, rainiest period). To avoid bias in data gathering the social worker was not told to which group each family belonged. During her visit she recorded who was sick, what kind of sickness it was and what treatment had been given. The latter included all the measures taken by the mother to heal the patient including traditional medicine, visiting the doctor or other means they were used. Furthermore, she wrote down if the episode mentioned was different from that of the previous week, mainly in the case of colds or chronic discases.

The data were analyzed first by comparing the two groups according to simple variables and by building indexes. The latter were: 1) Marital satis- faction which included three variables: 1.1) satisfaction with family life, which is a self-evaluation procedure undertaken by mothers. A 5-point scale (where $1=$ completely satisfied and $5=$ completely dissatisfied) was used. Mothers only marked the alternative which best seemed to fit their condition; 1.2) understanding with her partner; this is a question in which mothers themselves evaluate what they think of their partncr by rating this on a 5point scale (from $1=$ complcte understanding by their partner to 5 = a total lack of understanding); 1.3) frequency of arguments, this question also includes 5 time categories. Scores ranged from 1 (less than once every 2 months) to 5 (once or more a week). The index was expressed as a dichotomy: Low and High Marital Satisfaction. 2) SES, this index determined the sociocconomic status of each family. It discriminates even within a homogeneous socioeconomic population. The SES index is made up of 13 variables (number of people in the family group, presence of the father, schooling and activity of the head of the household, social security, ownership of the housc, quality of the house, crowding, availability of drinking water and sewerage, garbage disposal, separate kitchen and electrical houschold goods) with scores between 1 and 6 . The maximum possible score is 78 which means extreme poverty and the lowest is 13 which represents the highest level. Families in this study had scores that ranged betwcen 36 and 63 . The results showed a dichotomy of Low and Medium Low SES within a scale that considers: High, Medium High, Mcdium, Medium Low and Low9. 3) Health Condition of the Family, this was determined by the total number of individuals who, each week, showed any disease and/or illness.

The number of episodes per family varied between 3 and 46 throughout the observation period. The index is expressed as a dichotomy: the mean was 13 persons reporting some illness, therefore, families reporting more than 13 were considered as "Ill" while those reporting less than 13 were considered healthy. The sample was also analyzed according to marital satisfaction and crossed with the number of diseases which appeared in the family group throughout the whole period.

Fisher's Test was applied since the sample was small. Chi square and $t$ Student wore applicd where results allowed.

\section{Results}

The demographic characteristics of the sample were very similar in both groups. Both belonged to the low SES according to the spccific SES Scale ${ }^{1}$ (53.3\% A vs $46.7 \%$ B), each family group was 
formed on the average by 5.4 (Group A) and 5.1 (Group B) individuals; the father's age varied mostly between 30 and $40(66.6 \%$ Group $A$ and $53.3 \%$ Group B). Within each group, 3 grandmothers took care of the health of the family: their mean age was 55 years in Group A and 62.3 in Group B. The average number of children per family was 3.06 in Group A and 2.8 in Group B (SD 1.16 Group $A$ and 1.082 Group $B, t=n s$ ). The age of the children varied between 4 months and 15 years, ( 4 months -6 years; $46.2 \%$ Group $A$ and $54.7 \%$ Group B; $6-10$ years $35.5 \%$ in Group $A$ and $26.2 \%$ in Group B; $10-15$ years $17.9 \%$ in Group $A$ and $19.1 \%$ in Group B, Chi Square $=0.883$ ns, 2 d.f.).

The great majority of mothers were in charge of the health of their family $193.3 \%$ in Group A and $80 \%$ in Group B), the rest were in the care of grandmothers.

Table 1 shows maternal perception of the understanding received from their partncr. Slightly over a half of the Group A mothers felt that they were completely and very well understood compared to Group B in which the great majority expressed the same feclings.

Table 2 shows the frequency with which arguments in the couple end up in fights. Most of Group A mothers stated that they had this kind of argument as compared to only one third in Group B.

Table 3 shows the Marital Satisfaction Index. The majority of Group A mothers showed low

Table 1. Maternal perception of understanding with her partner in sick $(A)$ and healthy $(B)$ families

\begin{tabular}{lrrrrrrr}
\hline $\begin{array}{l}\text { Degree of } \\
\text { understanding }\end{array}$ & $\mathrm{N}$ & $\%$ & $\mathrm{~N}^{\mathrm{B}}$ & $\%$ & $\mathrm{~N}$ & $\%$ \\
\hline $\begin{array}{l}\text { Completely and well } \\
\text { understood }\end{array}$ & 8 & 53.3 & 11 & 91.6 & 19 & 70.4 \\
$\begin{array}{l}\text { More or less and not } \\
\text { understood }\end{array}$ & 7 & 46.7 & 1 & 8.4 & 8 & 29.6 \\
\hline Total & 15 & 100.0 & 12 & 100.0 & 27 & 100.0 \\
\hline $\begin{array}{l}3 \text { mothers did not have partners } \\
F P<0.037\end{array}$ & & & & & & & \\
\hline
\end{tabular}

Table 2. Arguments between the couple in sick (A) and healthy $(B)$ families

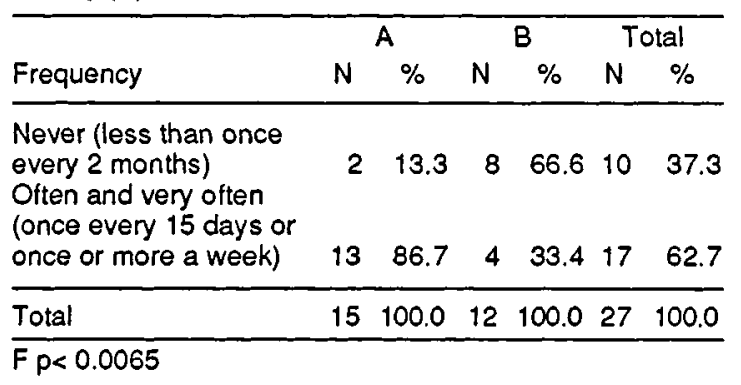

marital satisfaction, as compared to less than half of those in Group B.

Table 4 shows how the mother acquired information about health. Sixty-six per cent of the mothers in Group A learned about health care from their own mothers as opposed to the great majority in Group B. Information was also received by both groups from doctors, paramedical personncl and relatives, with no differences between the groups.

Table 5 indicates what actions mothers take to preserve or improve the health of their families. Both groups considered food and hygiene to be fundamental for these purposes $(66.6 \%$ vs $60 \%$ and $40 \%$ vs $53.3 \%$, respectively). Mothers in Group A stated that health is something to be well taken care of, significantly more often than those in Group B ( $p<.01)$. On the contrary, the latter fecl that the quality of the environment is more important for good health; no mother in Group A mentioned the environment ( $p<.04)$.

When a family member became sick, the customary bchavior of mothers in both groups was to

Table 3. Marital satisfaction index in sick (A) and healthy (B) families

\begin{tabular}{lrrrrrrr}
\hline \multirow{2}{*}{ Satifaction } & \multicolumn{2}{c}{ A } & \multicolumn{3}{c}{ B } & \multicolumn{2}{c}{ Total } \\
\hline Low & $N$ & $\%$ & $N$ & $\%$ & $N$ & $\%$ \\
\hline High & 13 & 86.6 & 5 & 41.6 & 18 & 66.6 \\
\hline Total & 2 & 13.4 & 7 & 58.4 & 9 & 33.4 \\
\hline
\end{tabular}

$F p<0.019$

Table 4. Person who taught health care to sick $(A)$ and healthy $(B)$ families

\begin{tabular}{|c|c|c|c|c|c|}
\hline \multirow[b]{2}{*}{ Person } & \multicolumn{2}{|c|}{$A$} & \multicolumn{2}{|c|}{$B$} & \multirow{2}{*}{$\begin{array}{l}F \\
P\end{array}$} \\
\hline & $N$ & $\%$ & $\mathrm{~N}$ & $\%$ & \\
\hline Mother & 10 & 66.6 & 14 & 93.3 & $<.05$ \\
\hline Physician & 10 & 66.6 & 8 & 53.3 & ns \\
\hline Paramedical & 8 & 53.3 & 6 & 40.0 & ns \\
\hline Relatives & 7 & 46.6 & 6 & 40.0 & ns \\
\hline Friends & 3 & 20.0 & 3 & 20.0 & ns \\
\hline Other health personnel & 3 & 20.0 & 3 & 20.0 & ns \\
\hline
\end{tabular}

Table 5. Behaviors in the search for health as seen by the mother in sick $(A)$ and healthy $(B)$ families

\begin{tabular}{lccr}
\hline & $\begin{array}{c}A \\
(N=15) \\
\%\end{array}$ & $\begin{array}{c}B \\
(N=15) \\
\%\end{array}$ & $F$ \\
Beliefs & 66.6 & 60.0 & $n s$ \\
Feeding & 60.0 & 20.0 & $p<.01$ \\
Health care & 40.0 & 53.3 & $n s$ \\
Hygiene & 0.0 & 26.6 & $p<.04$ \\
Adequate environment & 6.6 & 13.3 & $n$ ns \\
Other & & & \\
\hline
\end{tabular}


Table 6. Health condition of the families during 6-month follow-up in sick $(A)$ and healthy $(B)$ families

\begin{tabular}{lcccccc}
\hline \multirow{2}{*}{ Health condition } & N & $\%$ & N & $\%$ & N & $\%$ \\
\hline III & 163 & 45.3 & 121 & 33.7 & 284 & 39.4 \\
Healthy & 197 & 54.7 & 239 & 66.7 & 436 & 60.6 \\
\hline Total & 360 & 100.0 & 360 & 100.0 & 720 & 100.0 \\
\hline$X^{2} 0=10.257$ & \multicolumn{4}{c}{$\mathrm{p}<.01$} & 1 D.F.
\end{tabular}

Table 7. Low marital satisfaction of the mother and diseases in sick $(A)$ and healthy $(B)$ families

\begin{tabular}{lrrrrrrr}
\hline & \multicolumn{3}{c}{$\mathrm{A}$} & \multicolumn{3}{c}{$\mathrm{B}$} & \multicolumn{2}{c}{ Total } \\
Diseases & $\mathrm{N}$ & $\%$ & $\mathrm{~N}$ & $\%$ & $\mathrm{~N}$ & $\%$ \\
\hline Respiratory & 140 & 70.3 & 38 & 55 & 195 & 72.7 \\
Other & 59 & 29.7 & 31 & 45 & 90 & 27.3 \\
\hline Total & 199 & 100.0 & 69 & 100 & 285 & 100.0 \\
\hline$X^{2} 0=4.699$ & P<.03 & 1D.F. & &
\end{tabular}

Table 8. High marital satisfaction of the mother and diseases in sick $(A)$ and healthy $(B)$ families

\begin{tabular}{lccccccc}
\hline & \multicolumn{3}{c}{$\mathrm{A}$} & \multicolumn{3}{c}{ B } & \multicolumn{2}{c}{ Total } \\
Diseases & $\mathrm{N}$ & $\%$ & $\mathrm{~N}$ & $\%$ & $\mathrm{~N}$ & $\%$ \\
\hline Respiratory & 43 & 70.5 & 55 & 64 & 98 & 66.6 \\
Other & 18 & 29.5 & 31 & 36 & 49 & 33.4 \\
\hline Total & 61 & 100.0 & 86 & 100 & 147 & 100.0 \\
\hline$X^{2}{ }_{0}=0.423$ & \multicolumn{6}{c}{ ns } & 1D.F.
\end{tabular}

seek help from outpatient clinics (51\% vs $48 \%$ ); to a lesser extent they resorted to self-medication ( $20.8 \%$ vs $27.3 \%$ ) or traditional medicine (herbs and other traditional cures) (18.4\% vs $14 \%)$.

Table 6 shows the health condition of family members during the follow-up period. According to the index, close to one half of Group A families were ill, compared to one third of those in Group B $(p<.01)$.

When the level of marital satisfaction of mothers was compared to the incidence of discase, families with low marital satisfaction who belonged to Group A had significantly more members with respiratory diseases than Group B (Table 7). There were no differences between the groups when mothers with a high degrce of marital satisfaction were compared during follow-up (Table 8).

\section{Discussion and Conclusions}

The management of health within the family group has been the object of few studies because patients usually appear as isolated cases that are treated without inquiring, in more detail, who takes care of them. In this study, interest was focused on the mother because she is usually in charge of family health care $5,6,7,13$. In Groups $A$ and $B$ mothers were in charge of their family's health $(93.3 \%$ and $80 \%$ respectively). In the remaining families, it was in the hands of grandmothers. We postulate that the health of the family depends in part on the marital satisfaction of the mother, on her knowledge, beliefs and praclices and on the health system she chooses for treatment. To search for evidence in support of this postulate, a homogeneous group of familics of low SES was selected and followed up for 6 months. Maternal behavior and knowledge about health care and the quality of their relationships with their partners were evaluated. The study then compares two groups of families in this universe. One, considered "sick" in which one or more of their members had symptoms requiring help from one of the health systems within three months prior to the first interview. The other, consisting of the "healthy" families, namely those that did not require help from the health systems over the same period. The sociocconomic and demographic characteristics of both groups were similar, which prevented the attribution of the differences encountered to these variables.

The variables studicd, which deal with interpersonal relations between the couple, were found to be significantly more deteriorated in the "sick" than in the "healthy" families. This supports our postulates concerning the influence of the mother's marital satisfaction on the health care she seeks or provides. It is difficult for a mother, who does not feel understood and/or has constant arguments with her partner, to fecl satisfied with her life. She can be considered a person under stress ${ }^{12,14,19,21}$. The first to feel the negative effects of this dissatisfaction are the members of her own family, because of the unfavorable effect this has her mood. Bccause one of her main concerns relates to the maintenance of family health, this aspect tends to become neglected.

An important difference between the two groups relates to the sources of information about health care. While more than half of the mothers of the "sick" families learned from their own mother, the latter were the source for almost all the mothers of "healthy" families $(p<.05)$. This is to be explained by the rural origin of the latter $(\mathrm{p}<$ .01) where the influence of tradition is still strong. Both groups resort, in comparable proportions, to the exogenous health system because the National Health Service has been in operation for more than 30 years. This means that this probably influences both groups in similar ways. This applies to the bchaviors used to maintain good health ${ }^{15}$. 
The only difference is that mothers in Group B take into consideration and give value to the quality of the environment in the maintenance of health $(\mathrm{p}<.04)$.

One of the characteristics of deprivation is the inability to criticize and this could be happening to mothers of sick families who, in addition to socioeconomic deprivation, have low levels of marital satisfaction $4,12,17$.

The fact that families considered "sick" and "healthy", at the beginning of the study, remaincd in that condition during the whole follow-up period, would indicate that the selection process had been carried out correctly and that other factors might explain the state of family health. This could be explained by the presence of chronic diseases. However, there were only 5 cases in the whole sample: 4 cases among the sick families (3 adults and 1 child) and one case among healthy families. Marital satisfaction appears to be important for family health. Mothers of "sick" families who had low levels of marital satisfaction had significantly more diseases, mainly respiratory, in their families than those of "heal thy" families $(\mathrm{p}<.03)$. The fact that there were more respiratory discases fits in with data provided annually by the National Hcalth Service, since this is the highest cause of morbidity on the national level ${ }^{14}$.

Studies of other socioeconomic levels have been made to assess whether, in these groups too, low marital satisfaction leads mothers to neglect their family's health. If this were the case, familics should be encouraged to find better balance and understanding so that they may obtain better health.

ALVAREZ, M. L. \& WURGAFT, F. Saúde e pobreza: o controle da saúde pela mulher. Rev. Saúde públ., S. Paulo, 26: 82-7, 1992. Foi realizado estudo prospectivo relacionando a satisfação da mãe com sua vida marital e o estado de saúde da familia de nível socioeconômico baixo. A amostra estudada consistiu de 30 familias com crianças menores de 7 anos: 15 consideradas "doentes" (grupo A) e 15 "sãs" (grupo B). Os dois grupos não diferiram em relação à idade dos pais, número de pessoas na faminia, idade das crianças e nível socioeconômico. Os resultados mostraram que as mães eram responsávcis pela saúde da família. As do grupo A cram significativamente menos compreendidas e eram menos satisfeitas que as do grupo $B(p<0,05 \mathrm{e} p<0,01)$. As mães do grupo $A$ brigavam mais com seus parceiros $(p<0,006)$ do que as do grupo B. As crianças do grupo A aprendiam menos de suas mães quanto aos cuidados da saúde do que as do B. As mães do grupo $A$ acreditavam que a saúde era "algo a ser levado em conta" mais do que no grupo $B$ ( $p<0,05$ e $p<0,01$ ). Ambos os grupos não diferiam em relação ao serviço de saúde a escolher. $A$ insatisfação materna foi associada com famílias com crianças com patologia, durante os seis meses do seguimento. Sugere-se que a insatisfação materna é fator que necessita de maiores investigações, porque a saúde é amplamente conitrolada pelas mães.

Descritores: Mães. Satisfação pessoal. Saúde da familia. Pobreza.

ALVAREZ, M. L. \& WURGAFT, F. [Salud y pobreza: cl control de la salud por la mujer]. Rev. Saúde públ., S. Paulo, 26: 82-7, 1992. El objetivo de este estudio de seguimiento fue relacionar la salisfacción de la madre en su vida marital con el estado de salud de su familia en el nivel sociocconómico (NSE) bajo. La muestra estuvo formada por 30 familias con ninös menores de 7 anõs: 15 consideradas "enfermas" (Grupo A) y 15 "sanas" (Grupo B). Ambos grupos eran similares en sus características demográficas (edad del padre y de la madre, $\mathrm{n}^{\mathbf{e}}$ de personas en el grupo familiar y edad de los hijos) y NSE. Los resultados mostraron que las madres eran principalmente las encargadas de la salud familiar. Las madres del Grupo A eran significativamente menos comprendidas y más insatisfechas que aquellas del Grupo B $(\mathrm{p}<.05$ y $\mathrm{p}<.01)$. Las madres del Grupo A tenían mucho más discusiones con su pareja que aquellas del Grupo B $(p<.006)$. Los cuidados de salud fueron menos aprendidos de sus madres que aquellas del Grupo B $(p<.05)$. La salud fue considerada por las madres del Grupo A como algo "que se debe tomar en cuenta" mucho más que las del Grupo B ( $p<.01)$. Las conductas de las madres en la clección del sistema de salud a escoger fue similar en ambos grupos. La insatisfacción materna estuvo asociada más con las familias con miembros enfermos durante los seis meses de seguimiento. Sugerimos que la satisfacción de la madre es un factor que necesita scr más investigado, porque la salud es ampliamente manejada por las madres.

Descriptores: Madres. Satisfacción personal. Salud de la familia. Pobreza.

\section{Referências Bibliográficas}

1. ALVAREZ, M.L.; WURGAFT, F;; SALAZAR, M. E. Mediciones del nivel socicconómico bajo urbano en familias con lactante desnutrido. Arch. latinoamer. Nutr. 32: 650-2, 1982.

2. ALVAREZ, M. L. Deprivación y familia. Santiago, Ed. Universitaria, 1982.

3. APPI:LS, A. Culture and disease. Soc. Sci. Med., 23: 477. 83, 1986.

4. BLAXTER, M. Sclf definition of health status and consulting rates in primary care. Quart.J. soc. Affairs, 1: 131, 1985.

5. CHILMAN, C. Families in poventy in the early 1970: rates, associated factors, some implications. J. Marriage and Fam. 37: 49, 1975.

6. COMINSKY, S. \& SCRIMSHIANP, M. Medical pluralism on a Guatemalan plantation. Soc.Sci.Med, 14B: 267-78,1980.

7. ESCOBAR, G. J.; SALAZAR, E.; CHUY, M. Beliefs regarding the etiology and treatment of infantile diarrhoca in Lima, Peru. Soc. Sci. Med., 17: 1257-69, 1983. 
8. FINERMAN, D. R. A matter of life and death: health care change in an Andean community. Soc. Sci. Med., 18: 329-34, 1984.

9. FOSTER, G. M. Anthropological research perspective on health problems in developing countries. Soc. Sci. Med. 18: 847,1984

10. FOSTER, G.M. How to stay well in Tzintzuntzan. Soc. Sci. Med., 19: 523-33, 1984.

11. GOLOMB, L. The interplay of traditional therapies in South Thailand. Soc. Sci. Med., 27: 761-8, 1988.

12. INSTITUTO NACIONAL DE ESTADISTICAS (Chile). Anuario de Egresos Hospilalarios: 1985. Santiago, Chile, 1987.

13. KROEGER, A. Anthropological and socio-medical health care research in developing countries. Soc. Sci.Med. 17: $147-61,1983$.

14. KULYS, R. \& MEYER, R. Good health: whose responsability? Soc. Work Hlih Care, 11: 63-4, 1985.

15. MAES, S.; VINGERHOETS, A.; VAN HECK, G. The study of stress and disease: some developments and requirements. Soc. Sci. Med., 25: 567-8, 1987.

16. MARIN van OSS, B.; MARIN, G.; PADILLA A.M.; DE LA ROCHA, C. Utilization of traditional and non traditional sources of health care among Hispanic. Hispanic J. behav. Sci., 5: 65, 1983.
17. PEDERSEN, D. \& COLONIA, C. Traditional medicine in Ecuador: the structure of the non formal health system. Soc. Sci.Med., 17: 1249-55, 1983.

18. PEDERSON, D. \& BARUFFATI, V. Health and traditional medicine cultures in Latin America and the Caribbean. Soc. Sci. Med., 21: 5-12, 1985.

19. SHARP, S. A. Folk medicine practices: women as keepers and carriers of knowledge. Women's Stud. Int. Forum, 9: 243-9, 1986.

20. VINGERHOETS, A. \& MARCELISSEN, F. H. G. Stress research: its present status and issues for future developments. Soc. Sci. Med., 26: 279-91, 1988.

21. WINBERLEY, D. W. Sociceconomic deprivation and religions salience: a cognitive bchavioral approach. Sociol. Quart., 25: 223-8, 1984.

22. YOUNG, A. The relevance of traditional medical cultures to modern primary health care. Soc. Sci. Med., 17: 1205-11, 1983.

23. ZEMPLENI, A. Entre 'Sickness et Illness': de la socialisation et l'individualisation de la 'Maladie'. Soc. Sci. Med., 27: 1171-2, 1988.

Received for publication: $26 / 6 / 1991$

Reviewed in: 29/10/1991

Accepted for publication: 14/11/1991 